\title{
Overall assessment of antibiotic substitutes for pigs: a set of meta-analyses
}

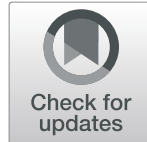

Bocheng Xu, Jie Fu, Luoyi Zhu, Zhi Li, Mingliang Jin and Yizhen Wang ${ }^{*}$ [D

\begin{abstract}
Background: Antibiotic growth promoters are widely used to improve weight gain. However, the abuse of antibiotics can have many negative effects on people. Developing alternatives to antibiotics is an urgent need in livestock production. We aimed to perform a meta-analysis and network meta-analysis (NMA) to investigate the effects of feed additives as potential antibiotic substitutes (ASs) on bacteriostasis, growth performance, intestinal morphology and immunity. Furthermore, the primary, secondary, and tertiary ASs were defined by comparing their results with the results of antibiotics.
\end{abstract}

Results: Among 16,309 identified studies, 37 were summarized to study the bacteriostasis effects of feed additives, and 89 were included in the meta-analysis and NMA (10,228 pigs). We summarized 268 associations of 57 interventions with 32 bacteria. The order of bacteriostasis effects was as follows: antimicrobial peptides (AMPs) $\approx$ antibiotics>organic acids $>$ plant extracts $>$ oligosaccharides. We detected associations of 11 feed additives and 11 outcomes. Compared with a basal diet, plant extract, AMPs, probiotics, microelements, organic acids, bacteriophages, lysozyme, zymin, and oligosaccharides significantly improved growth performance $(P<0.05)$; organic acids, probiotics, microelements, lysozyme, and AMPs remarkably increased the villus height:crypt depth ratio $(V / C)(P<0.05)$; and plant extracts, zymin, microelements, probiotics, and organic acids notably improved immunity $(P<0.05)$. The optimal AMP, bacteriophage, lysozyme, microelements, oligosaccharides, organic acids, plants, plant extracts, probiotics, and zymin doses were $0.100 \%, 0.150 \%, 0.012 \%, 0.010 \%, 0.050 \%, 0.750 \%, 0.20 \%, 0.040 \%, 0.180 \%$, and $0.100 \%$, respectively. Compared with antibiotics, all investigated feed additives exhibited no significant difference in effects on growth performance, lgG, and diarrhoea index/rate $(P>0.05)$; AMPs and microelements significantly increased V/C $(P<0.05)$; and zymin significantly improved lymphocyte levels $(P<0.05)$. Furthermore, linear weighting sum models were used to comprehensively estimate the overall impact of each feed additive on pig growth and health.

Conclusions: Our findings suggest that AMPs and plant extracts can be used as primary ASs for weaned piglets and growing pigs, respectively. Bacteriophages, zymin, plants, probiotics, oligosaccharides, lysozyme, and microelements can be regarded as secondary ASs. Nucleotides and organic acids can be considered as tertiary ASs. Future studies should further assess the alternative effects of combinational feed additives.

Keywords: Antibiotic substitutes, Dose-effect relationship, Feed additives, Meta-analysis, Network meta-analysis, Pigs

\footnotetext{
*Correspondence: yzwang321@zju.edu.cn

National Engineering Laboratory of Biological Feed Safety and Pollution Prevention and Control, Key Laboratory of Animal Nutrition and Feed of Ministry of Agriculture, Key Laboratory of Animal Nutrition and Feed Science of Zhejiang Province, Institute of Feed Science, Zhejiang University, 866 Yuhangtang Road, Hangzhou 310058, Zhejiang Province, People's Republic of China
}

(c) The Author(s). 2021 Open Access This article is licensed under a Creative Commons Attribution 4.0 International License, which permits use, sharing, adaptation, distribution and reproduction in any medium or format, as long as you give appropriate credit to the original author(s) and the source, provide a link to the Creative Commons licence, and indicate if changes were made. The images or other third party material in this article are included in the article's Creative Commons licence, unless indicated otherwise in a credit line to the material. If material is not included in the article's Creative Commons licence and your intended use is not permitted by statutory regulation or exceeds the permitted use, you will need to obtain permission directly from the copyright holder. To view a copy of this licence, visit http://creativecommons.org/licenses/by/4.0/ The Creative Commons Public Domain Dedication waiver (http://creativecommons.org/publicdomain/zero/1.0/) applies to the data made available in this article, unless otherwise stated in a credit line to the data. 


\section{Background}

Antibiotics are widely used in commercial pig production for growth promotion and disease prevention [1]. Subtherapeutic doses of antibiotics are used as feed additives to promote growth performance, improving average daily gain (ADG) and gain:feed ratio (G/F) through alterations in intestinal morphology and digestion and the suppression of harmful bacteria [2]. However, feeding pigs subtherapeutic doses of antibiotics in the long term leads to the development of antimicrobial resistance, which is seriously endangering public health [3]. Considering its harm, in 1999, the European Union banned the use of subtherapeutic doses of antibiotics in livestock [3]. In 2017, the FDA reported that antibiotics that are important for human medicine could no longer be used for growth promotion in food animals [4]. Notably, China will completely ban the use of antibiotics in feed in 2020 [5]. Therefore, governments and world organizations have initiated a series of countermeasures and encouraged the research and development of antibiotic substitutes (ASs). However, some questions about ASs are the following. 1) How should ASs be defined? 2) What are the effects of many feed additives on bacteriostasis, growth promotion, improvement of intestinal morphology and immunity? 3) What is the optimal dose for these feed additives? 4) Which additive is the most powerful AS? In this study, we performed a set of metaanalyses to investigate the effects of different feed additives regarded as ASs on growth performance, intestinal morphology and immunity in pigs. Then, we used network meta-analyses (NMAs) to assess and compare the effects of antibiotics and different ASs that are superior to the basal diet. Finally, we used a linear weighted model to evaluate ASs. To the best of our knowledge, this study is the first to comprehensively and systematically define ASs and investigate their effects.

\section{Methods}

This meta-analysis is reported according to the Preferred Reporting Items for Systematic Reviews and MetaAnalyses (PRISMA) Statement [6] and the Approach of Meta-analysis on Nonruminants [7, 8].

\section{Search strategy}

We performed a series of meta-analyses of studies on potential ASs indexed on PubMed from January 1, 2000 to April 31, 2019, and the language was restricted to English. The complete search strategy is shown in Table S1. Moreover, studies on antimicrobial peptides (AMPs) were identified by searches in the Antimicrobial Peptide Database (http://aps.unmc.edu/AP/, accessed on April 31, 2019). In addition, a manual search was performed to obtain additional potential studies.

\section{Selection criteria}

The inclusion criteria were as follows: 1) studies investigating the effects of ASs on bacteriostasis; 2) studies investigating the effects of potential ASs as feed additives on pig growth performance, the villus height:crypt depth ratio, blood haematology, or diarrhoea; and 3) studies in which the breeding background was commercial pigs. The exclusion criteria were as follows: 1) studies on antibacterial effects that did not report minimum inhibitory concentrations (MICs) or animal-specific bacteria; 2) studies without a basal diet or a positive control group; 3) studies where pig growth was not assessed in stages; 4) studies in which pigs were challenged with pathogenic bacteria, viruses, or lipopolysaccharide; 5) studies that included multiple factors; and 6) studies in which pigs exhibited an oxidative stress status or a heat stress state.

Three investigators (B. Xu, L. Zhu and J. Fu) reviewed study titles, abstracts, and full texts to ensure studies satisfied the inclusion criteria, and disagreements were resolved by two investigators ( $\mathrm{M}$. Jin and Y. Wang).

\section{Information extraction}

The following data were extracted from each selected study: author information (first author, year, country), interventions, control group, breeding background, amount of additive, growth stages (weaned piglets, growing pigs, finishing pigs), sample size, initial and final body weight, experimental duration, and outcome data and corresponding errors, such as standard deviations or standard errors. The initial body weight of weaned piglets was lower than $15 \mathrm{~kg}$, the initial body weight of growing pigs was more than $15 \mathrm{~kg}$, and the initial body weight of finishing pigs was more than $45 \mathrm{~kg}$. Outcomes were as follows: MIC; ADG; average daily feed intake (ADFI); G/F; V/C of duodenum, jejunum, and ileum; immune globulin (Ig), including IgA, IgM, and IgG; lymphocyte levels, diarrhoea rate, and diarrhoea index. For studies involving multiple interventions, we extracted data from all relevant interventions. For studies involving multiple concentrations, we extracted all the experimental groups with an addition amount less than $1 \%$. When extractions from different plant tissues were used, we chose leaf extractions.

\section{Study quality assessment}

We conducted a study quality assessment on nonruminants (SQANR) to assess the quality of existing studies [7]. The potential risk of bias was derived from missing within-group error, repeated reports, information completeness, sample size, and experimental rationality. Two investigators (B. Xu and L. Zhu) performed independent study quality assessments. 


\section{Statistical analysis}

We aimed to compare which ASs were most suitable in terms of bacteriostasis, growth promotion and disease resistance effects. First, we compared the effects of basal diet with those of feed additive supplementation on a range of outcomes. We used a random-effects model to compute the pooled estimate of standardized mean difference (SMD) with the 95\% confidence interval (CI). If the $95 \%$ CI contained a zero value, that result indicated that there was no difference. The heterogeneity was assessed with the $I^{2}$ statistic [9] and Cochran's $Q$ test [10]; $I^{2}>50 \%$ and $P_{\text {heterogeneity }}<0.1$ was regarded as a substantial heterogeneity.

We used sensitivity analyses to remove individual data values with large deviations from the overall level. If 10 or more trials were available, we conducted subgroup analyses and meta-regression to explore potential sources of heterogeneity. Publication bias was evaluated using Egger's tests, for which the significance level was defined at $P<0.1$ [11]. Second, if the data were sufficient, we used the dose-effect model to find the optimal amount of added feed additives. When the same effect size occurred at different concentrations, we chose the lowest concentration to reduce the cost. Third, we performed an NMA to further study feed additives that, when compared with basal diet, had a significant effect on growth performance. We aimed to compare the growth performance effects of feed additives with the optimal amount of ASs added. NMA enables the incorporation of indirect comparisons constructed from two trials with the same control group. NMA combined all available comparisons among ASs and provided a ranking of suitable alternatives to antibiotics [12]. To explore evidence of within-network inconsistency, the loopspecific approach was used [13].

We used Stata 14.0 (Stata Corp., USA) to perform the meta-analysis. We used R 3.6.1 (The R Foundation Conference Committee, USA) to examine the dose-effect relationship and perform the NMA.

\section{Assessment of antibiotic substitutes}

We aimed to use a linear weighting sum model to comprehensively assess the efficacy of feed additives. In terms of bacteriostasis, according to the order of occurrences, 4 bacteria were chosen from gram-positive/negative bacteria for analysis. We used the rank score of the interventions to assess their bacteriostasis effects based on MICs. We used the P-score value, which evaluates and ranks the strength of the intervention from the NMA, to grade available interventions. Each $P$-score value of feed additives was subtracted by that of the corresponding basal diet, which was performed to guarantee a consistent background. When feed additives were not included in the NMA or were not observed in the outcomes, the feed additives were rated zero in the corresponding outcomes. For growth performance, the weights of ADG, ADFI, and G/F were $30 \%, 10 \%$, and $60 \%$, respectively. For intestinal morphology, the weights of $\mathrm{V} / \mathrm{C}$ of the duodenum, jejunum, and ileum were $30 \%$, $10 \%$, and $60 \%$, respectively. For immunity, the weights of IgA, IgM, IgG, and lymphocyte levels and diarrhoea index/rate were $10 \%, 10 \%, 10 \%, 10 \%, 60 \%$, respectively. The overall score was equal to the sum of the score of bacteriostasis, growth performance, intestinal morphology, and immunity effects multiplied by the corresponding weight (bacteriostasis $=10 \%$; growth performance $=50 \%$; intestinal morphology $=10 \%$; immunity $=30 \%$ ). Furthermore, we also conducted the stage scores based on the growth stage to provide a special strategy. Feed additives that were superior to antibiotics on the stage scores were regarded as primary ASs. Feed additives that were superior to antibiotics on one outcome were regarded as secondary ASs. Finally, the remaining feed additives were regarded as tertiary ASs.

\section{Results}

We identified 16,309 articles in PubMed, of which 89 were included in the meta-analyses [14-102], including 10,228 pigs, and 37 were summarized to investigate the antibacterial effects of feed additives [103-139]. The characteristics of the studies are shown in Table S2. The study quality assessed by SQANR is shown in Table S3. The number of studies rated as "high" and "moderate" were 7 and 61, respectively. The mean initial body weights of weaned piglets, growing pigs, and finishing pigs were $7.7 \mathrm{~kg}, 28.4 \mathrm{~kg}$, and $57.6 \mathrm{~kg}$, respectively. Feed additives included plant extracts, plants, probiotics, microelements, organic acids, bacteriophages, lysozyme, zymin, AMPs, nucleotides, and oligosaccharides. The results of the meta-regression are shown in Table 1 . The different growth stages had a significant influence on ADFI and $\mathrm{G} / \mathrm{F}(P<0.05)$, while the type of feed additives and dose did not have a significant effect on the outcomes of interest $(P>0.05)$. Therefore, when we performed meta-analyses for growth performance, the growth stages were divided into weaned piglets, growing pigs, and finishing pigs.

\section{Effects of feed additives on bacteriostasis}

We summarized 268 associations of 57 interventions with 32 bacteria (Table S4). Due to the number of associations, Staphylococcus aureus and Bacillus subtilis were used to represent gram-positive bacteria, and Escherichia coli and Pseudomonas aeruginosa were used to represent gram-negative bacteria. Overall, based on the rank score, bacteriostasis effects of interventions were as follows (Table 2): AMPs $\approx \mathrm{ASs}>$ organic acids $>$ plant extracts $>$ oligosaccharides, which were in 
Table 1 Regression analyses of the covariates

\begin{tabular}{llll}
\hline Outcomes & Type of feed additive & Growth stage & Dose \\
\hline Average daily gain & 0.986 & 0.064 & 0.954 \\
Average daily feed intake & 0.105 & 0.001 & 0.466 \\
Gain: feed ratio & 0.414 & 0.009 & 0.082 \\
Villus height: crypt depth of the duodenum & 0.474 & 0.974 & 0.949 \\
Villus height: crypt depth of the jejunum & 0.168 & 0.514 & 0.989 \\
Villus height: crypt depth of the ileum & 0.021 & 0.989 & 0.397 \\
IgA & 0.278 & 0.591 & 0.597 \\
IgM & 0.552 & 0.449 & 0.886 \\
IgG & 0.354 & 0.661 & 0.976 \\
Lymphocytes & 0.156 & $\mathrm{NA}$ & 0.978 \\
Diarrhoea rate & 0.587 & $\mathrm{NA}$ & $\mathrm{NA}$ \\
Diarrhoea index & 0.535 & 0.053 \\
\hline
\end{tabular}

accordance with bacteriostasis effects of those interventions on gram-positive or gram-negative bacteria.

\section{Effect of feed additives on growth performance}

As shown in Fig. 1a-i and Table S5, compared with a basal diet, plants and probiotics had significant effects on ADG at all stages $(P<0.05)$, plant extracts and zymin improved weaned and growing pigs' ADG $(P<0.05)$, and bacteriophages, lysozyme, and AMPs had significant effects on weaned piglets' ADG $(P<0.05)$, while only microelements and organic acids had no significant effect on growing pigs' ADG $(P>0.05)$. With regard to ADFI, probiotics, microelements, organic acids, bacteriophages, lysozyme, AMPs, and oligosaccharides had a notable effect on weaned piglets $(P<0.05)$, while we detected that organic acids improved ADFI in growing pigs $(P<0.05)$ and that probiotics had a negative impact on finishing pigs' ADFI $(P<0.05)$. In terms of $\mathrm{G} / \mathrm{F}$, plants remarkably improved weaned and growing pigs' G/F $(P<0.05)$, probiotics had a significant effect on weaned and finishing pigs' $\mathrm{G} / \mathrm{F}(P<0.05)$, and microelements, organic acids, bacteriophages, lysozyme, zymin, AMPs, and oligosaccharides had considerable effects on weaned piglets' $\mathrm{G} / \mathrm{F}(P<0.05)$.

Figure 2 show the dose-effect relationship among the feed additives and growth performance. The optimal doses of AMPs, bacteriophages, lysozyme, microelements, oligosaccharides, organic acids, plants, plant extracts, probiotics, and zymin were $0.100 \%, 0.150 \%, 0.012 \%, 0.010 \%$, $0.050 \%, 0.750 \%, 0.20 \%, 0.040 \%, 0.180 \%$, and $0.100 \%$, respectively.

Figure 3 and Table 3 show the comparison between antibiotics and feed additives based on NMA. Compared with those of antibiotics, feed additives that had a positive significant effect on growth performance compared with the basal diet had no difference in growth performance. For weaned piglets' ADG, the P-score values of bacteriophages, AMPs, lysozyme, and probiotics were greater than those of antibiotics. For weaned piglets' ADFI, the $P$-score value of AMPs was greater than that of antibiotics. For weaned piglets' G/F, the $P$-score values of AMPs, zymin, bacteriophages, and oligosaccharides were greater than those of antibiotics. For growing pigs' ADG, the $P$-score values of probiotics, plants, and plant extracts were greater than those of antibiotics. For finishing pigs' ADG, the $P$ score value of plants was greater than that of antibiotics. However, we did not observe a $P$-score value of feed additives greater than that of antibiotics for ADFI and G/F of growing and finishing pigs.

\section{Effect of feed additives on intestinal morphology}

As shown in Fig. 1j-1 and Table S5, probiotics, organic acids, microelements, lysozyme, AMPs, plant extracts significantly improved the $\mathrm{V} / \mathrm{C}$ of duodenum and ileum

Table 2 The rank of bacteriostasis effects

\begin{tabular}{lllll}
\hline Interventions & Staphylococcus aureus & Bacillus subtilis & Escherichia coli & Pseudomonas aeruginosa \\
\hline Antimicrobial peptides & 1 & 2 & 1 & 2 \\
Antibiotics & 2 & 1 & 2 & 1 \\
Organic acids & 3 & 2 & 3 & 3 \\
Plant extracts & 4 & 4 & 4 & 4 \\
Oligosaccharides & 5 & 5 & 4 & NA \\
\hline
\end{tabular}




\section{Growth performance}

ADG
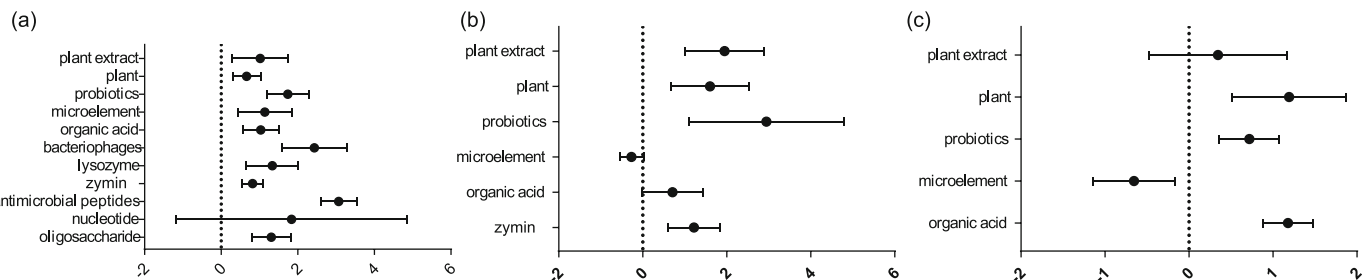

ADFI

(d)

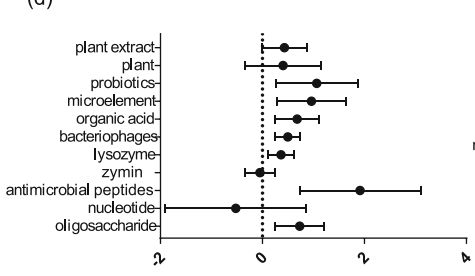

(e)

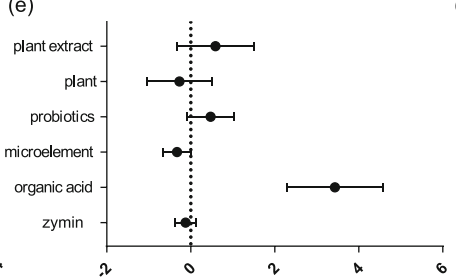

(f)

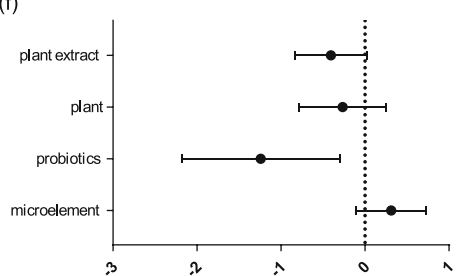

$\mathrm{G} / \mathrm{F}$

(g) (h)

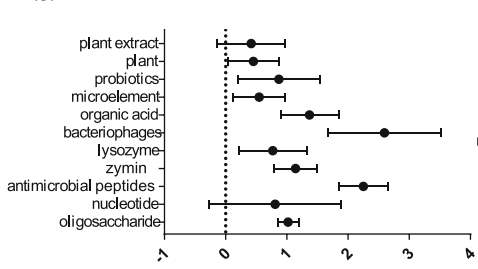

(h)
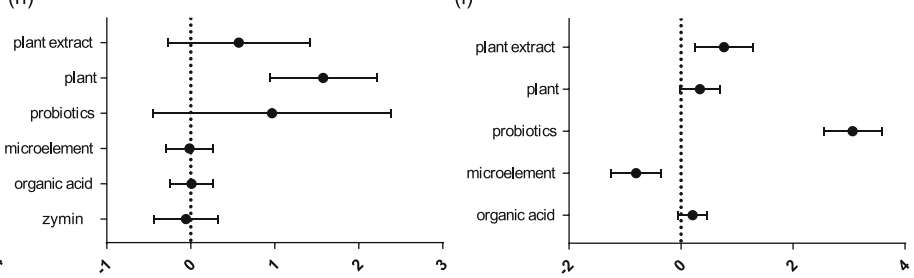

Villus height: crypt depth

(j)

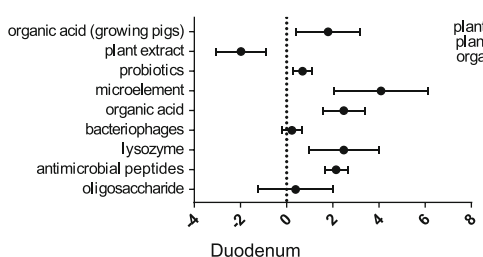

Immunity

(m)

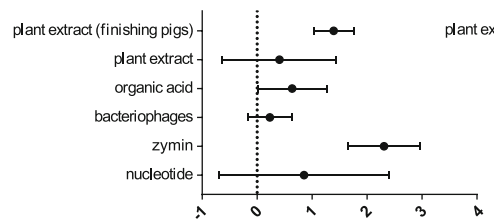

$\lg \mathrm{A}$

(p)

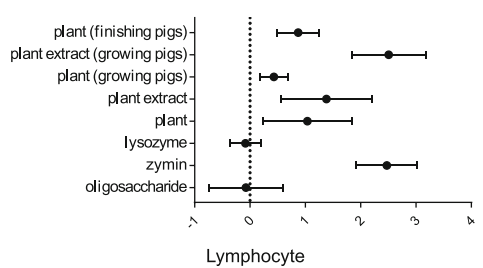

(k)

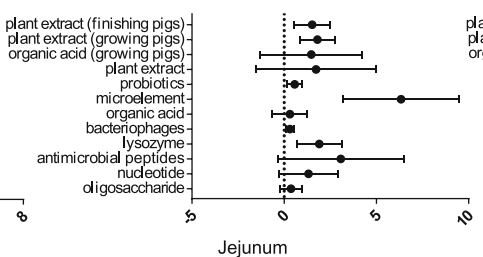

(n) (l)

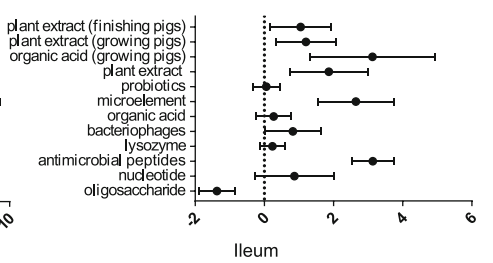

(o)
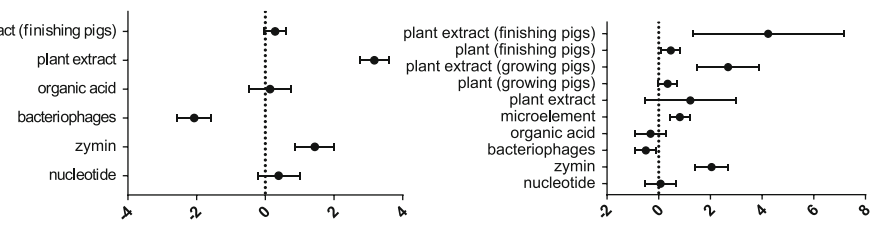

$\lg G$

(q)

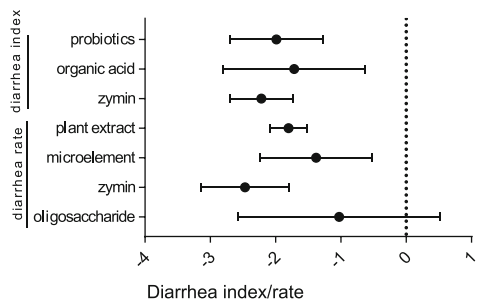

Fig. 1 (See legend on next page.) 
(See figure on previous page.)

Fig. 1 Summary forest plots of the effects of feed additives. a Feed additives and weaned piglets' average daily gain. b Feed additives and growing pigs' average daily gain. $\mathbf{c}$ Feed additives and finishing pigs' average daily gain. $\mathbf{d}$ Feed additives and weaned piglets' average daily feed intake. e Feed additives and growing pigs' average daily feed intake. $\mathbf{f}$ Feed additives and finishing pigs' average daily feed intake. $\mathbf{g}$ Feed additives and weaned piglets' gain:feed ratio. $\mathbf{h}$ Feed additives and growing pigs' gain:feed ratio. $\mathbf{i}$ Feed additives and finishing pigs' gain:feed ratio. $\mathbf{j}$ Feed additives and villus height:crypt depth ratio of the duodenum. $\mathbf{k}$ Feed additives and villus height:crypt depth ratio of the jejunum. $\mathbf{i}$ Feed additives and villus height:crypt depth ratio of the ileum. $\mathbf{m}$ Feed additives and IgA level. $\mathbf{n}$ Feed additives and lgM level. o Feed additives and lgG level. $\mathbf{p}$ Feed additives and lymphocytes. q Feed additives and diarrhoea index/rate

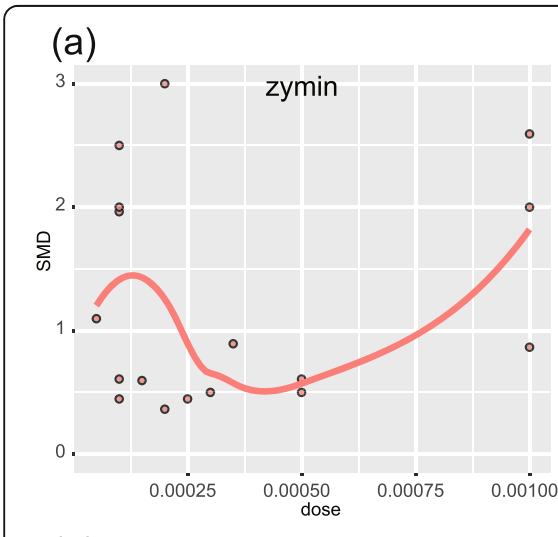

(b)

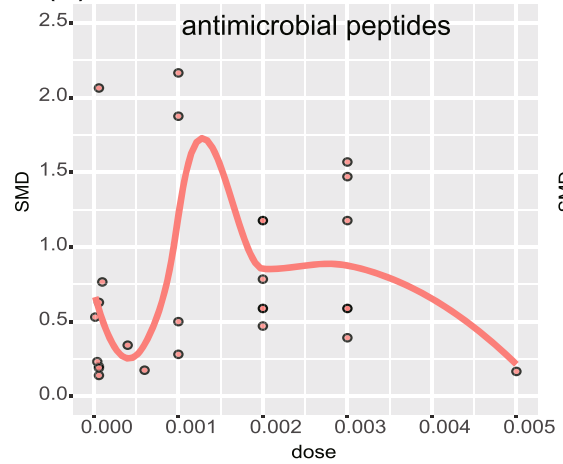

(e)

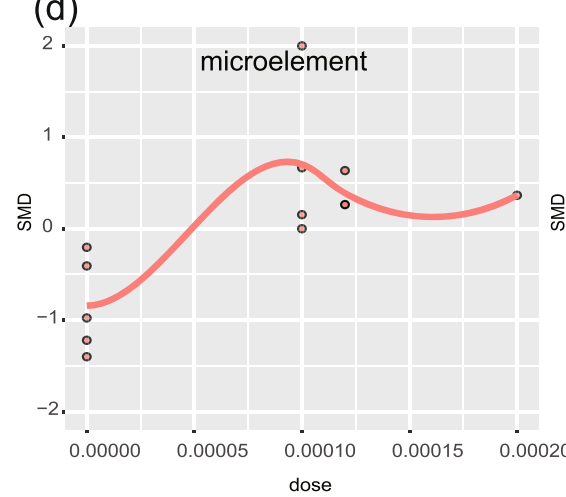

(g)

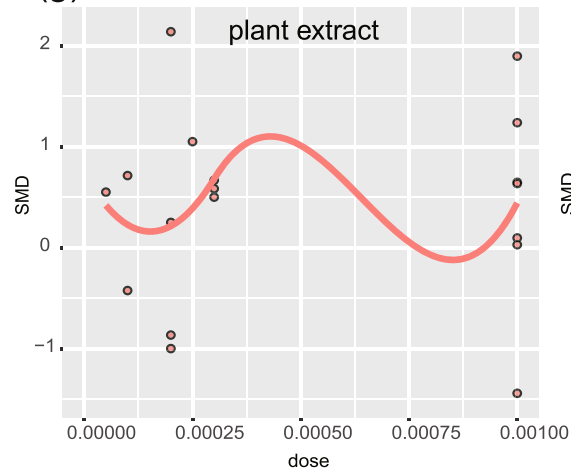

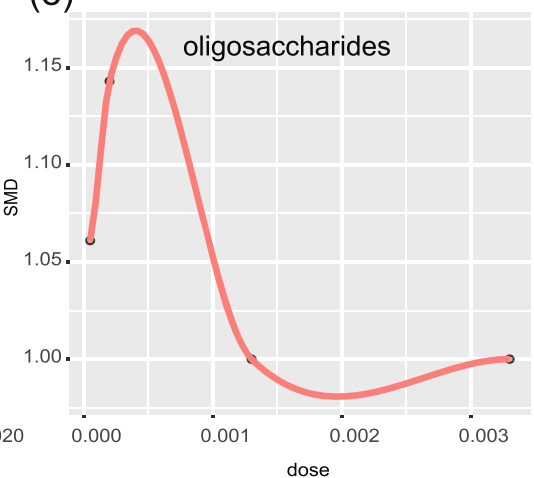

(h)

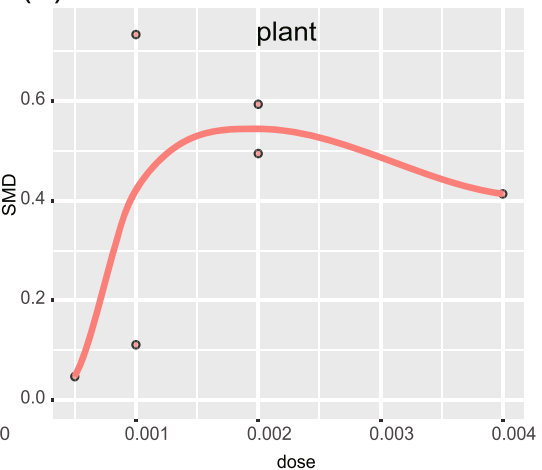

(c)

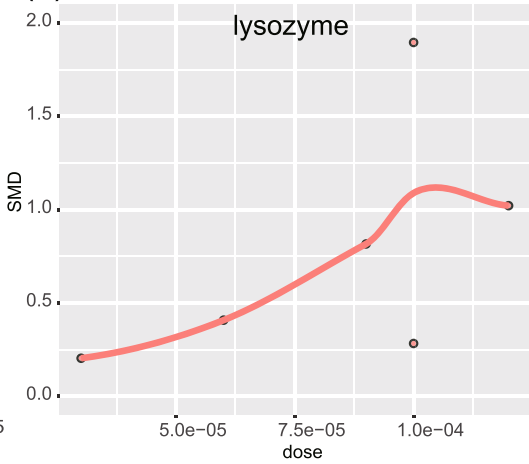

(f)

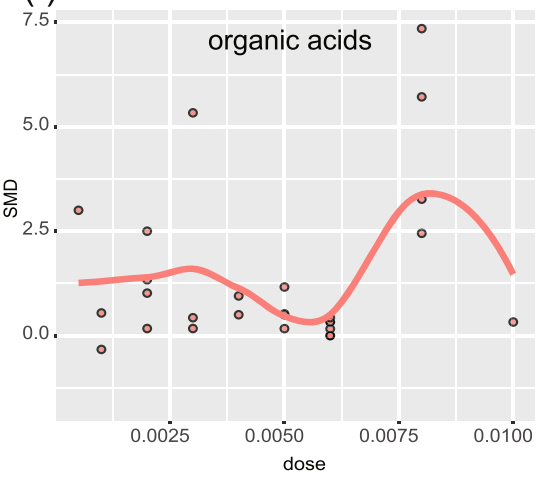

(i)

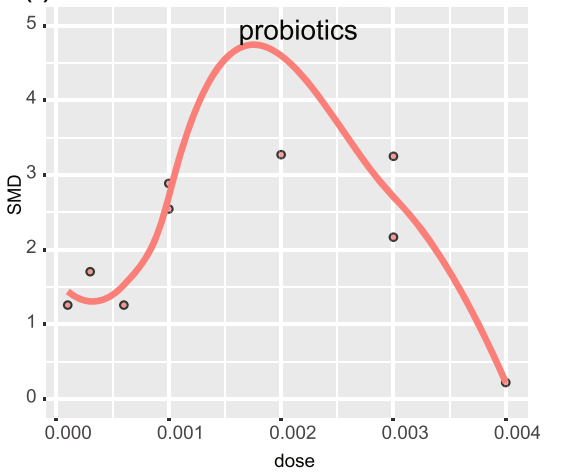

Fig. 2 Dose-effect relationship between feed additives and growth performance. a Zymin. b Antimicrobial peptides. c Lysozyme. d Microelement. e Oligosaccharides. f Organic acids. g Plant. h Plant extract. i Probiotics 


\section{Growth performance}

Average daily gain

(a)

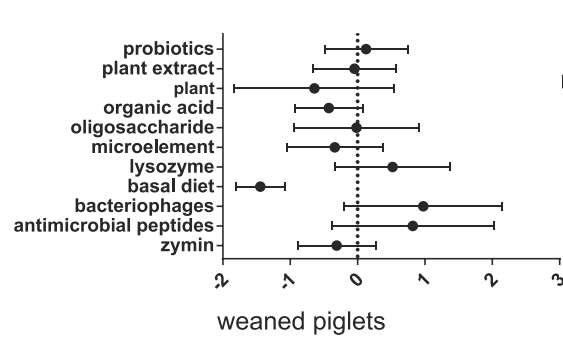

Average daily feed intake

(d)

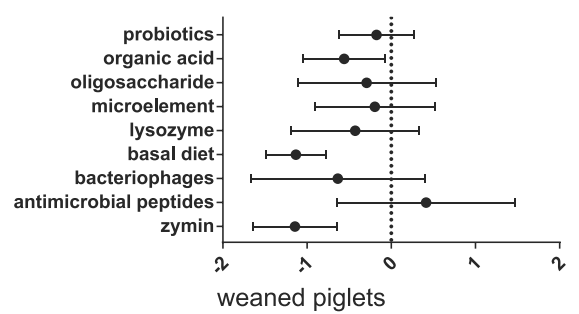

Villus height: crypt depth

(f)

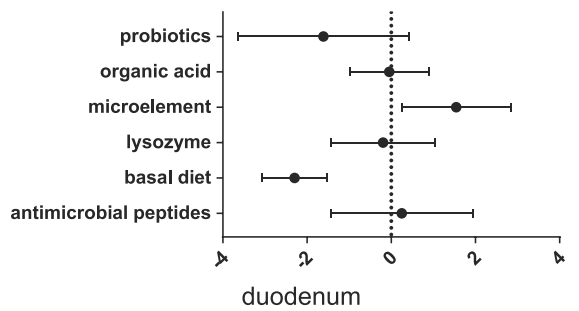

(b)

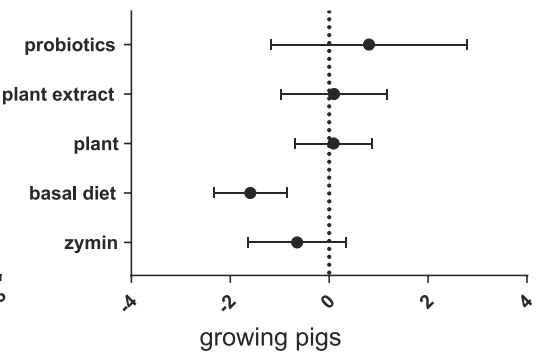

(c)

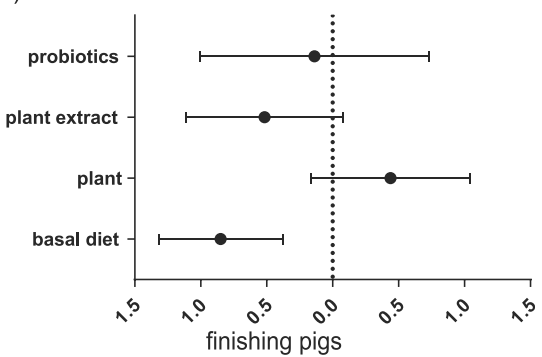

Gain: feed ratio

(e)

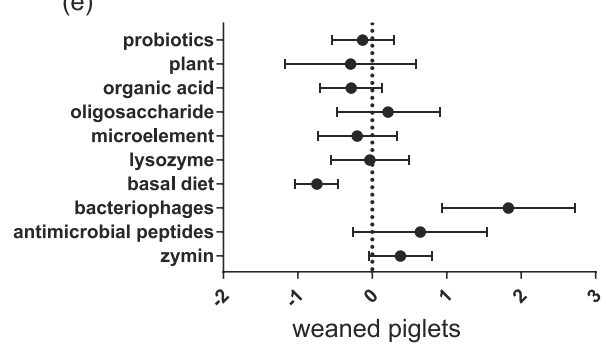

(g)

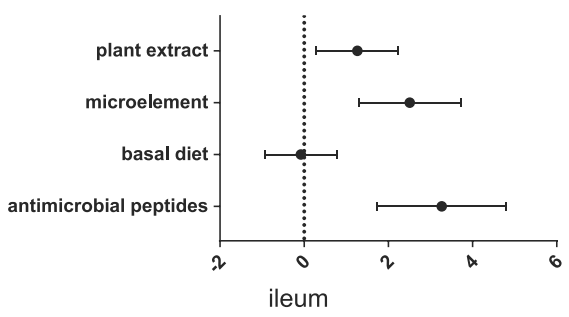

Immunity

(h)

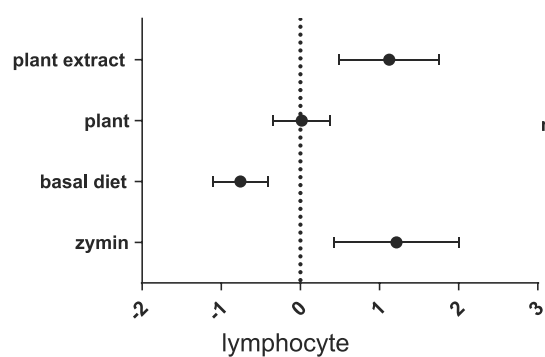

(i)

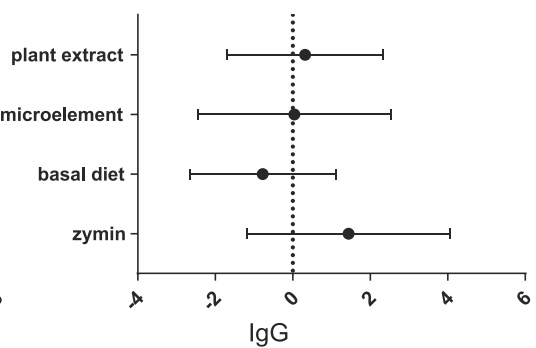

(j)

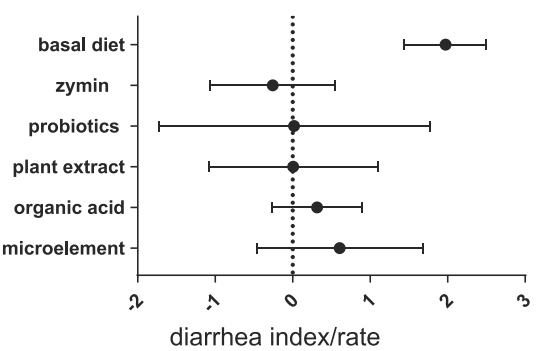

Fig. 3 Forest plots of network meta-analysis. a Feed additives and weaned piglets' average daily gain. b Feed additives and growing pigs' average daily gain. $\mathbf{c}$ Feed additives and finishing pigs' average daily gain. $\mathbf{d}$ Feed additives and weaned piglets' average daily feed intake. e Feed additives and weaned piglets' gain:feed ratio. f Feed additives and villus height:crypt depth ratio of the duodenum. $\mathbf{g}$ Feed additives and villus height:crypt depth ratio of the ileum. $\mathbf{h}$ Feed additives and lymphocytes. $\mathbf{i}$ Feed additives and IgG level. $\mathbf{j}$ Feed additives and diarrhoea index/rate 
Table 3 P-score value table

\begin{tabular}{lllllllllll}
\hline Interventions & ADG-w & ADG-g & ADG-f & G/F-w & ADFI-w & V/C (duodenum) & V/C (ileum) & Lymphocytes & IgG & Diarrhoea rate/index \\
\hline Antibiotics & 0.552 & 0.589 & 0.628 & 0.493 & 0.723 & 0.542 & 0.037 & 0.366 & 0.337 & 0.664 \\
Antimicrobial peptides & 0.852 & 0.000 & 0.000 & 0.796 & 0.820 & 0.615 & 0.841 & 0.000 & 0.000 & 0.000 \\
Bacteriophages & 0.898 & 0.000 & 0.000 & 0.980 & 0.299 & 0.000 & 0.000 & 0.000 & 0.000 & 0.000 \\
Basal diet & 0.000 & 0.000 & 0.000 & 0.000 & 0.000 & 0.000 & 0.000 & 0.000 & 0.000 & 0.000 \\
Lysozyme & 0.790 & 0.000 & 0.000 & 0.454 & 0.412 & 0.467 & 0.000 & 0.000 & 0.000 & 0.000 \\
Microelements & 0.331 & 0.000 & 0.000 & 0.319 & 0.568 & 0.937 & 0.686 & 0.000 & 0.370 & 0.327 \\
Oligosaccharides & 0.524 & 0.000 & 0.000 & 0.622 & 0.500 & 0.000 & 0.000 & 0.000 & 0.000 & 0.000 \\
Organic acids & 0.256 & 0.000 & 0.000 & 0.244 & 0.311 & 0.519 & 0.000 & 0.000 & 0.000 & 0.433 \\
Plants & 0.235 & 0.647 & 0.914 & 0.286 & 0.000 & 0.000 & 0.000 & 0.385 & 0.000 & 0.000 \\
Plant extracts & 0.515 & 0.646 & 0.252 & 0.000 & 0.000 & 0.000 & 0.399 & 0.856 & 0.496 & 0.735 \\
Probiotics & 0.625 & 0.843 & 0.531 & 0.371 & 0.587 & 0.139 & 0.000 & 0.000 & 0.000 & 0.000 \\
Zymin & 0.334 & 0.266 & 0.000 & 0.755 & 0.001 & 0.000 & 0.000 & 0.893 & 0.740 & 0.807
\end{tabular}

$w$ Weaned piglets, $g$ Growing pigs, $f$ Finishing pigs

in weaned piglets $(P<0.05)$, while plant extracts notably improved the $\mathrm{V} / \mathrm{C}$ of jejunum and ileum in growing and finishing pigs $(P<0.05)$.

As shown in Fig. 3f-g and Table 3, in weaned piglets, microelements were greater than AS on V/C of the duodenum and ileum, plant extracts and AMPs were greater than AS on V/C of the ileum, and probiotics, organic acids, lysozyme, and AMPs had no difference with AS on $\mathrm{V} / \mathrm{C}$ of the duodenum. Specifically, the $P$-score value of microelements and AMPs was greater than that of AS on $\mathrm{V} / \mathrm{C}$ of ileum.

\section{Effect of feed additives on immunity}

As shown in Fig. 1m-q and Table S5, plant extracts, zymin, and microelements were associated with improved Ig levels $(P<0.05)$; plants, plant extracts, and zymin were associated with improved lymphocyte levels $(P<0.05)$; and probiotics, organic acids, zymin, plant extracts, and microelements were associated with reduced diarrhoea index/rate $(P<0.05)$.

Figure $3 \mathrm{~h}-\mathrm{j}$ and Table 3 show that compared with ASs, zymin significantly improved lymphocyte levels. In terms of $P$-score value, plant extracts and zymin were better than ASs at reducing and alleviating diarrhoea; plant extracts, zymin, and plants were better than ASs at increasing lymphocyte levels; and plant extracts, zymin, and microelements were better than ASs at increasing IgG levels.

\section{Feed additives assessment}

Table 4 shows the assessment score of feed additives. The findings suggest that AMPs could be regarded as primary ASs in weaned piglets and that plant extracts could be considered ASs in growing pigs. Secondary ASs included bacteriophages, zymin, plants, probiotics, oligosaccharides, lysozyme, and microelements. In terms of bacteriostasis, AMPs were observed to have an antibacterial effect similar to that of antibiotics. For growth performance, AMPs, bacteriophages, zymin, and oligosaccharides could replace antibiotics in weaned piglets; probiotics, plants, and plant extracts could replace antibiotics in growing pigs; and plants could replace antibiotics in finishing pigs. With regard to intestinal morphology, AMPs, plant extracts, and microelements were superior to antibiotics. Zymin and plant extracts were better than antibiotics at improving immunity.

\section{Discussion}

We used meta-analysis and NMA to define ASs. We detected the associations of 11 feed additives and 11 outcomes. The findings suggest that AMPs and plant extracts can be used as ASs for weaned piglets and growing pigs, respectively and that bacteriophages, zymin, plants, probiotics, oligosaccharides, lysozyme, and microelements can be regarded as secondary ASs (Fig. 4). Based on current data, the optimal AMPs, bacteriophage, lysozyme, microelements, oligosaccharides, organic acids, plants, plant extracts, probiotics, and zymin doses were $0.100 \%, 0.150 \%, 0.012 \%, 0.010 \%$, $0.050 \%, 0.750 \%, 0.20 \%, 0.040 \%, 0.180 \%$, and $0.100 \%$, respectively.

To determine whether a feed additive is an eligible AS, it is necessary to measure its alternative effects on growth promotion, intestinal morphology improvement, bacteriostasis and immunity. Chief among these effects is growth promotion dependent on G/F. Feed additives enhance growth performance through improving intestinal morphology, reducing pernicious bacteria, reducing anti-nutritional factors, or improving nutrient digestibility. We did not investigate the effects of feed additives on the latter two mechanisms because antibiotics have not been reported to have these effects in the primary 


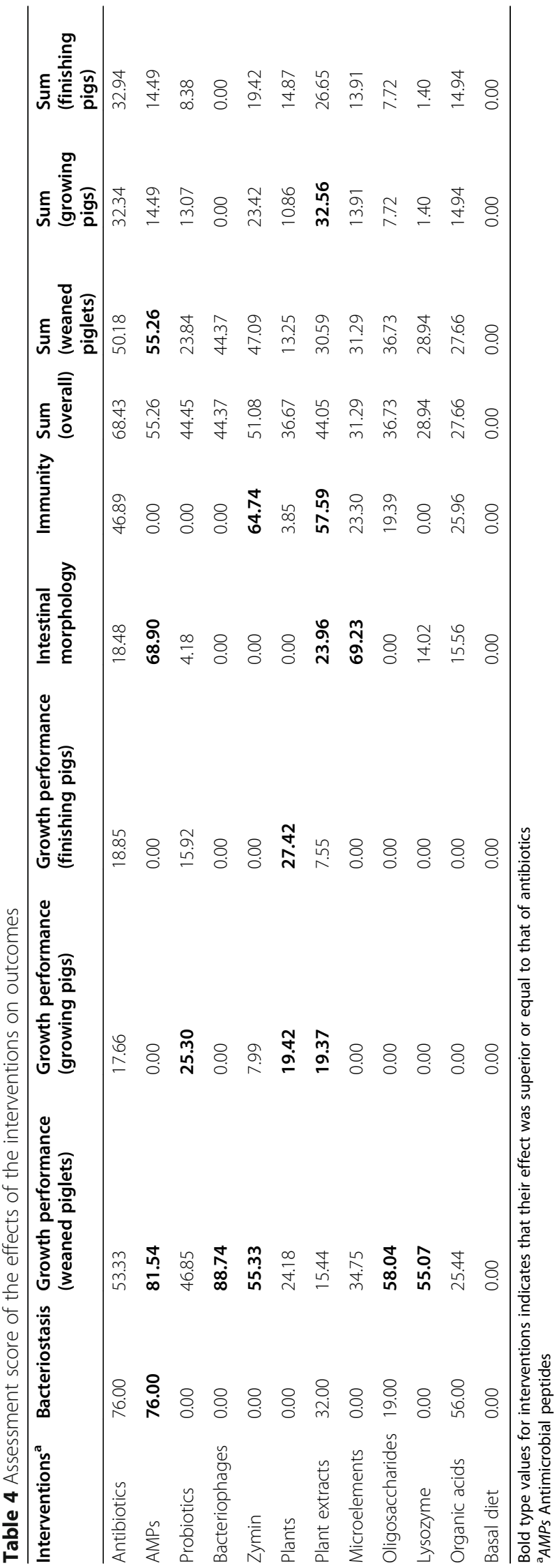




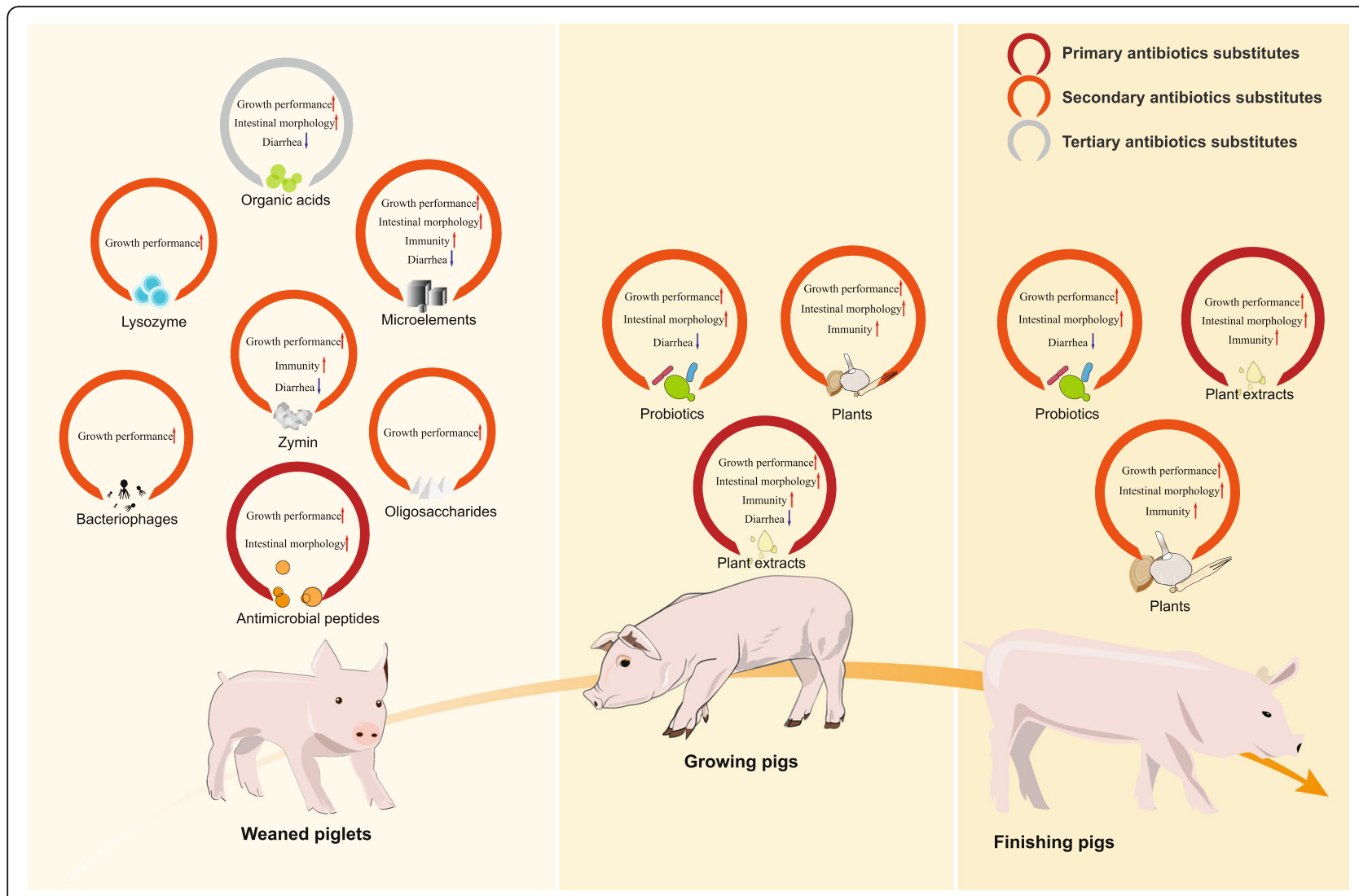

Fig. 4 Summary of findings of meta-analyses

studies included in this meta-analysis. We measured intestinal morphology through $\mathrm{V} / \mathrm{C}$, as $\mathrm{V} / \mathrm{C}$ is positively correlated with nutrient absorption capacity, such as that of carbohydrates and fatty acids [140]. We measured immunity through Ig and lymphocyte levels and the diarrhoea index/rate, which are the secondary phenotype outcomes. Consequently, antimicrobial and antiinflammatory properties also contribute to promotion of growth performance. Bacteriostasis is measured by in vitro $\mathrm{MIC}$ experiments that are considered to provide reliable and stable results. Meanwhile, bacteriostasis effects of interventions are linked to antidiarrhoeal properties to some extent.

Our findings, together with mechanisms and possible speculations reported in articles, provide rational interpretations for growth promotion, immunity enhancement, and antidiarrhoeal properties for ASs. Interpretations of primary ASs are as follows. 1) AMPs can promote growth performance (ADG, ADFI, G/F) by improving intestinal morphology $(\mathrm{V} / \mathrm{C}$ of the duodenum and ileum), nutrient digestibility, and antimicrobial activity [141]. AMPs can improve the duodenum and ileum by stimulating intestinal epithelial cell proliferation because AMP receptors may be rich in the duodenum and ileum [142]. AMPs are more likely to guarantee intestinal integrity and barrier function to protect from bacterial and toxin infections, which may be due to upregulation of the expression of tight junction proteins [102, 142, 143]. AMPs are critical components of the innate immune system, but evaluations of immune outcome associations were not conducted due to limitation by the lack of data. 2) Plant extracts can improve immunity (IgA, IgM, IgG, and lymphocyte levels) through their antimicrobial and antiinflammatory properties [65]. Changing the microbiota and regulating intestinal permeability contribute to their antidiarrhoeal properties. The effects of plant extracts on growth performance (ADG and G/F) exhibit substantial heterogeneity because numerous plant extracts were included, and there is no feasible subgroup. Growth promotion associated with improving nutrient digestibility and amino acid metabolism also occurred [14]. Our preanalyses identified a subgroup based on whether it is a plant essential oil, which cannot influence the substantial heterogeneity. A plant essential oil inhibits the opening of calcium channels and stimulates that of potassium channels in smooth muscles, which increases motility of the small intestine and produces a significant shortening of the food transit time [64, 144, 145]. However, several studies have suggested that a positive effect of plant 
essential oils seems to occur in challenged piglets rather than healthy piglets $[64,98]$. Future meta-analyses should study the effects of plant extracts in pigs with different health statuses and the main sources of heterogeneity based on a feasible subgroup.

Interpretations of secondary ASs are as follows. 1) Zymin can improve growth performance (ADG and G/F), enhance immunity (IgA, IgM, IgG, and lymphocyte levels), and reduce and relieve diarrhoea. The reason for the above phenotype is that zymin can increase digestive enzyme activities and nutrient digestibility and decrease Escherichia coli and Salmonella populations [100]. 2) Lysozyme can increase growth performance (ADG, ADFI, and $\mathrm{G} / \mathrm{F}$ ), improve intestinal morphology (V/C of the duodenum and jejunum), and increase lymphocyte levels. Lysozyme increases protein deposition and decreases the turnover rate of intestinal epithelial cells $[25,85]$. 3) Bacteriophages promote growth performance (ADG, ADFI, and G/F) through a reduction in coliforms and Clostridium [32]. 4) Plants can improve growth performance (ADG and G/F) and enhance immunity (IgG and lymphocyte levels). 4) Plants, specifically herbs, have antioxidant activity and pharmaceutical effects, providing additional benefits. Our previous meta-analysis indicated that fermented plants promoted growth performance and digestibility at all stages [8]. Additionally, fermented plants significantly improved marbling and decreased redness of the meat in finishing pigs but had no effect on lightness, yellowness, drip loss, and flavour [7]. 5) Probiotics can increase growth performance (ADG, ADFI, G/F) by improving nutrient digestibility and the microbiota structure, enhancing osmotic balance and reducing pernicious bacteria to contribute to the remission of diarrhoea [31]. Immunity promotion of probiotics was not observed; hence, the effect of probiotics on immunity is unclear. 6) Oligosaccharides can increase growth performance (ADG, ADFI, and G/F) and have no association with intestinal morphology, lymphocyte levels, or the diarrhoea rate. We speculate that oligosaccharides may increase nutrient digestibility, and the categories of oligosaccharides are related to the diarrhoea rate. 7) Microelements can increase growth performance (ADG, ADFI, and G/F), improve immunity (IgG levels), and reduce the risk of diarrhoea, which are linked to their bacteriostatic properties and improvement of the microbiota structure [74].

According to the results of the NMA, the effects of all feed additives investigated showed no significant difference from those of antibiotics on ADG, ADFI, IgG, and diarrhoea rate or index. The effects of bacteriophages are superior to those of antibiotics on weaned piglets' $\mathrm{G} / \mathrm{F}$; the effects of microelements, plant extracts, and AMPs are superior to those of antibiotics on improvement of intestinal morphology; and the effects of plant extracts and zymin are superior to those of antibiotics on lymphocyte level enhancement. All of the ASs have potential uses in animal health. However, the high cost for many ASs, such as AMPs and bacteriophages, may be prohibitive for animal use. Future studies should further investigate high-efficiency bacterial engineering, purification technology, and the design of novel AMPs to expedite progress in reducing and alternating antibiotics. Commitment to substantial subsidies might be needed to incentivize development of ASs for animal health, in which their use could contribute to a reduction in antibiotic use [146].

A major strength of the present study is that we investigated all feed additives mentioned as ASs, which thus comprehensively demonstrated the effects of each feed additive on outcomes for which producers and animal nutritionists are interested. A major innovation is that we used a rational approach, the linear weighting sum model, to estimate the overall impact of each feed additive and antibiotics on pig health and growth. The limitation of the present study is that we failed to further investigate the main sources of heterogeneity of every AS and effects of combinational feed additives, such as combinations of plant essential oils and organic acids and those of prebiotics and probiotics. Some ASs were downgraded due to lack of some outcomes data. Future studies should investigate effects of feed additives on various aspects beyond growth performance.

\section{Conclusions}

Here, we recommend supplementing 0.1\% AMPs in the weaned stage, adding $0.04 \%$ plant extract in the growing stage and feeding $0.2 \%$ plants, especially fermented plants, in the finishing stage, which may have an approximate effect compared with antibiotics on all stages. Our research is the first to define and overall assess ASs through metaanalysis and NMA. Although further research should supplement unobserved data for a more comprehensive assessment, our research clearly and systematically investigates AS candidates. However, it is important to note that there is no single alternative to completely substitute antibiotics in feed, and a combination of different alternatives to antibiotics may be the most promising method to reduce or replace antibiotics in animal feeds. Future meta-analyses should further study the alternative effects of combinational feed additives.

\section{Supplementary Information}

The online version contains supplementary material available at https://doi. org/10.1186/s40104-020-00534-2.

Additional file 1: Table S1. Search strategy. Table S2. Characteristics of studies. Table S3. Study quality assessment. Table S4. Minimal inhibitory concentration table $(\mu \mathrm{g} / \mathrm{mL})$. Table S5. Meta-analyses and subgroup analyses. 


\section{Abbreviations}

ADFI: Average daily feed intake; ADG: Average daily gain;

AMPs: Antimicrobial peptides; ASs: Antibiotic substitutes; Cl: Confidence interval; G/F: Gain: Feed ratio; SD: Standard deviation; SE: Standard error; SMD: Standard mean difference; SQANR: Study quality assessment on nonruminants; V/C: Villus height:crypt depth ratio

\section{Acknowledgements}

BX sincerely appreciates his parents for their support through this period.

\section{Authors' contributions}

BX conceived the idea for the study. BX and JF selected the studies for inclusion. BX, JF, and LZ extracted the data for meta-analysis. BX, LZ and JF assessed the quality of the included trials. BX and JF performed the statistical analyses. YW and MJ oversaw the development of the study and resolved conflicts in the meta-analysis. BX wrote the first draft. YW and MJ critically revised the paper for important intellectual content. All authors approved the final draft. YW had final responsibility for the decision to submit the paper for publication.

\section{Funding}

This study was supported by the Key Program of the National Natura Science Foundation of China (3163000269), National Special Fund for Modern Industrial Technology System (CARS-35), and Major Science and Technology Special Fund of Zhejiang Province (2015C02022).

\section{Availability of data and materials}

All data generated or analysed during this study are included in this published article.

\section{Ethics approval and consent to participate}

Not applicable.

\section{Consent for publication}

Not applicable.

\section{Competing interests}

The authors declare that they have no competing interests.

\section{Received: 7 June 2020 Accepted: 1 December 2020}

\section{Published online: 07 January 2021}

\section{References}

1. Cromwell GL. Why and how antibiotics are used in swine production. Anim Biotechnol. 2002;13:7-27

2. Van Boeckel TP, Brower C, Gilbert M, Grenfell BT, Levin SA, Robinson TP, et al. Global trends in antimicrobial use in food animals. Proc Natl Acad Sci U S A. 2015:112:5649-54.

3. Marshall BM, Levy SB. Food animals and antimicrobials: impacts on human health. Clin Microbiol Rev. 2011;24:718-33.

4. US Food and Drug Administration. Summary report on antimicrobials sold or distributed for use in food-producing animals. 2018. https://www.fda. gov/downloads/Forlndustry/UserFees/AnimalDrugUserFeeActADUFA/ UCM628538.pdf. Accessed 27 May 2019.

5. Ministry of Agriculture and Rural Affairs of the People's Republic of China. Notice of the ministry of agriculture and rural affairs office on the pilot work on the reduction of the use of veterinary antimicrobial drugs. 2018. http:// www.moa.gov.cn/govpublic/SYJ/201804/t20180420_6140711.htm. Accessed 27 May 2019.

6. Moher D, Liberati A, Tetzlaff J, Altman DG, Prisma Group. Preferred reporting items for systematic reviews and meta-analyses: the PRISMA statement. PLoS Med. 2009;6:e1000097.

7. $\quad X u$ B, Zhu L, Fu J, Li Z, Wang Y, Jin M. Overall assessment of fermented feed for pigs: a series of meta-analyses. J Anim Sci. 2019;97:4810-21.

8. Xu B, Li Z, Wang C, Fu J, Zhang Y, Wang Y, et al. Effects of fermented feed supplementation on pig growth performance: a meta-analysis. Anim Feed Sci Technol. 2020;259:114315.

9. Higgins JP, Thompson SG. Quantifying heterogeneity in a meta-analysis. Stat Med. 2002;21:1539-58,

10. Higgins JP, Thompson SG, Deeks JJ, Altman DG. Measuring inconsistency in meta-analyses. BMJ. 2003;327:557-60.
11. Eng C, Kramer CK, Zinman B, Retnakaran R. Glucagon-like peptide-1 receptor agonist and basal insulin combination treatment for the management of type 2 diabetes: a systematic review and meta-analysis. Lancet. 2014;384:2228-34.

12. Palmer SC, Mavridis D, Nicolucci A, Johnson DW, Tonelli M, Craig JC, et al. Comparison of clinical outcomes and adverse events associated with glucose-lowering drugs in patients with type 2 diabetes: a meta-analysis. JAMA. 2016;316:313-24.

13. Veroniki AA, Vasiliadis HS, Higgins JP, Salanti G. Evaluation of inconsistency in networks of interventions. Int J Epidemiol. 2013;42:332-45.

14. Yin FG, Liu YL, Yin YL, Kong XF, Huang RL, Li TJ, et al. Dietary supplementation with Astragalus polysaccharide enhances ileal digestibilities and serum concentrations of amino acids in early weaned piglets. Amino Acids. 2009;37:263-70.

15. Chu GM, Jung CK, Kim HY, Ha JH, Kim JH, Jung MS, et al. Effects of bamboo charcoal and bamboo vinegar as antibiotic alternatives on growth performance, immune responses and fecal microflora population in fattening pigs. Anim Sci J. 2013;84:113-20.

16. Chu GM, Lee SJ, Jeong HS, Lee SS. Efficacy of probiotics from anaerobic microflora with prebiotics on growth performance and noxious gas emission in growing pigs. Anim Sci J. 2011;82:282-90.

17. Jeong JS, Kim IH. Effect of probiotic bacteria-fermented medicinal plants (Gynura procumbens, Rehmannia glutinosa, Scutellaria baicalensis) as performance enhancers in growing pigs. Anim Sci J. 2015;86:603-9.

18. Kang SN, Chu GM, Song YM, Jin SK, Hwang IH, Kim IS. The effects of replacement of antibiotics with by-products of oriental medicinal plants on growth performance and meat qualities in fattening pigs. Anim Sci J. 2012; 83:245-51.

19. Kim J, Kim J, Kim Y, Oh S, Song M, Choe JH, et al. Influences of quorumquenching probiotic bacteria on the gut microbial community and immune function in weaning pigs. Anim Sci J. 2018;89:412-22.

20. Lan R, Li T, Kim I. Effects of xylanase supplementation on growth performance, nutrient digestibility, blood parameters, fecal microbiota, fecal score and fecal noxious gas emission of weaning pigs fed corn-soybean meal-based diet. Anim Sci J. 2017;88:1398-405.

21. Lei XJ, Lee SI, Kim IH. Effects of different levels of dietary protein with or without plant extract YGF251 on growth performance, nutrient digestibility, blood profiles, fecal microbial shedding, and fecal gas emission in growing pigs. Anim Sci J. 2019;90:547-53.

22. Li J, Kim IH. Effects of Saccharomyces cerevisiae cell wall extract and poplar propolis ethanol extract supplementation on growth performance, digestibility, blood profile, fecal microbiota and fecal noxious gas emissions in growing pigs. Anim Sci J. 2014;85:698-705.

23. Li MZ, Huang JT, Tsai YH, Mao SY, Fu CM, Lien TF. Nanosize of zinc oxide and the effects on zinc digestibility, growth performances, immune response and serum parameters of weanling piglets. Anim Sci J. 2016;87: 1379-85.

24. Liu W, Devi S, Park J, Kim I. Effects of complex probiotic supplementation in growing pig diets with and without palm kernel expellers on growth performance, nutrient digestibility, blood parameters, fecal microbial shedding and noxious gas emission. Anim Sci J. 2018:89:552-60.

25. Long Y, Lin S, Zhu J, Pang X, Fang Z, Lin Y, et al. Effects of dietary lysozyme levels on growth performance, intestinal morphology, non-specific immunity and mRNA expression in weanling piglets. Anim Sci J. 2016;87: 411-8.

26. Qian $L$, Yue X, Hu L, Ma Y, Han X. Changes in diarrhea, nutrients apparent digestibility, digestive enzyme activities of weaned piglets in response to chitosan-zinc chelate. Anim Sci J. 2016;87:564-9.

27. Yan L, Meng QW, Kim IH. Effects of fermented garlic powder supplementation on growth performance, nutrient digestibility, blood characteristics and meat quality in growing-finishing pigs. Anim Sci J. 2012; 83:411-7.

28. Yeh $\mathrm{HS}$, Weng BC, Lien TF. Effects of Chinese traditional herbal medicine complex supplementation on the growth performance, immunity and serum traits of pigs. Anim Sci J. 2011;82:747-52.

29. Yen HC, Lai WK, Lin CS, Chiang SH. Medium-chain triglyceride as an alternative of in-feed colistin sulfate to improve growth performance and intestinal microbial environment in newly weaned pigs. Anim Sci J. 2015;86: 99-104.

30. Zhao P, Piao X, Zeng Z, Li P, Xu X, Wang H. Effect of Forsythia suspensa extract and chito-oligosaccharide alone or in combination on performance, 
intestinal barrier function, antioxidant capacity and immune characteristics of weaned piglets. Anim Sci J. 2017;88:854-62

31. Hancox LR, Le Bon M, Richards PJ, Guillou D, Dodd CE, Mellits KH. Effect of a single dose of Saccharomyces cerevisiae var. boulardii on the occurrence of porcine neonatal diarrhoea. Animal. 2015;9:1756-9.

32. Kim JS, Hosseindoust A, Lee $\mathrm{SH}$, Choi YH, Kim MJ, Lee JH, et al. Bacteriophage cocktail and multi-strain probiotics in the feed for weanling pigs: effects on intestine morphology and targeted intestinal coliforms and Clostridium. Animal. 2017;11:45-53.

33. Superchi P, Saleri R, Borghetti P, De Angelis E, Ferrari L, Cavalli V, et al. Effects of dietary nucleotide supplementation on growth performance and hormonal and immune responses of piglets. Animal. 2012;6:902-8.

34. Taylor AE, Bedford MR, Miller HM. The effects of xylanase on grower pig performance, concentrations of volatile fatty acids and peptide $Y Y$ in portal and peripheral blood. Animal. 2018;12:2499-504.

35. Waititu SM, Yin F, Patterson R, Yitbarek A, Rodriguez-Lecompte JC, Nyachoti CM. Dietary supplementation with a nucleotide-rich yeast extract modulates gut immune response and microflora in weaned pigs in response to a sanitary challenge. Animal. 2017;11:2156-64.

36. Walsh AM, Sweeney T, Bahar B, Flynn B, O'Doherty JV. The effects of supplementing varying molecular weights of chitooligosaccharide on performance, selected microbial populations and nutrient digestibility in the weaned pig. Animal. 2013;7:571-9.

37. Yoon JH, Ingale SL, Kim JS, Kim KH, Lee SH, Park YK, et al. Effects of dietary supplementation of antimicrobial peptide-A3 on growth performance, nutrient digestibility, intestinal and fecal microflora and intestinal morphology in weanling pigs. Anim Feed Sci Technol. 2012;177:98-107.

38. Cheng C, Xia M, Zhang X, Wang C, Jiang S, Peng J. Supplementing oregano essential oil in a reduced-protein diet improves growth performance and nutrient digestibility by modulating intestinal bacteria, intestinal morphology, and antioxidative capacity of growing-finishing pigs. Animals (Basel). 2018:8:159.

39. Cutler SA, Lonergan SM, Cornick N, Johnson AK, Stahl CH. Dietary inclusion of colicin e1 is effective in preventing postweaning diarrhea caused by F18positive Escherichia coli in pigs. Antimicrob Agents Chemother. 2007;51: 3830-5.

40. Li J, Li D, Gong L, Ma Y, He Y, Zhai H. Effects of live yeast on the performance, nutrient digestibility, gastrointestinal microbiota and concentration of volatile fatty acids in weanling pigs. Arch Anim Nutr. 2006; 60:277-88.

41. Nowak P, Kasprowicz-Potocka M, Zaworska A, Nowak W, Stefanska B, Sip A, et al. The effect of eubiotic feed additives on the performance of growing pigs and the activity of intestinal microflora. Arch Anim Nutr. 2017;71:455-69.

42. Partanen K, Siljander-Rasi H, Pentikainen J, Pelkonen S, Fossi M. Effects of weaning age and formic acid-based feed additives on pigs from weaning to slaughter. Arch Anim Nutr. 2007;61:336-56.

43. Upadhaya SD, Park JW, Lee JH, Kim IH. Efficacy of beta-mannanase supplementation to corn-soya bean meal-based diets on growth performance, nutrient digestibility, blood urea nitrogen, faecal coliform and lactic acid bacteria and faecal noxious gas emission in growing pigs. Arch Anim Nutr. 2016;70:33-43.

44. Vahjen W, Osswald T, Schafer K, Simon O. Comparison of a xylanase and a complex of non starch polysaccharide-degrading enzymes with regard to performance and bacterial metabolism in weaned piglets. Arch Anim Nutr. 2007;61:90-102.

45. Van Nevel CJ, Decuypere JA, Dierick NA, Molly K. Incorporation of galactomannans in the diet of newly weaned piglets: effect on bacteriological and some morphological characteristics of the small intestine. Arch Anim Nutr. 2005;59:123-38

46. Zhang S, Song J, Deng Z, Cheng L, Tian M, Guan W. Effects of combined alpha-galactosidase and xylanase supplementation on nutrient digestibility and growth performance in growing pigs. Arch Anim Nutr. 2017;71:441-54.

47. Pan B, Li D, Piao X, Zhang L, Guo L. Effect of dietary supplementation with alpha-galactosidase preparation and stachyose on growth performance, nutrient digestibility and intestinal bacterial populations of piglets. Arch Tierernahr. 2002;56:327-37.

48. Hu S, Wang Y, Wen X, Wang L, Jiang Z, Zheng C. Effects of low-molecularweight chitosan on the growth performance, intestinal morphology, barrier function, cytokine expression and antioxidant system of weaned piglets. BMC Vet Res. 2018;14:215.
49. Han XY, Ma YF, Lv MY, Wu ZP, Qian LC. Chitosan-zinc chelate improves intestinal structure and mucosal function and decreases apoptosis in ileal mucosal epithelial cells in weaned pigs. Br J Nutr. 2014;111:1405-11.

50. Molist F, Hermes RG, de Segura AG, Martin-Orue SM, Gasa J, Manzanilla EG, et al. Effect and interaction between wheat bran and zinc oxide on productive performance and intestinal health in post-weaning piglets. $\mathrm{Br} \mathrm{J}$ Nutr. 2011;105:1592-600

51. Tang Z, Yin Y, Zhang Y, Huang R, Sun Z, Li T, et al. Effects of dietary supplementation with an expressed fusion peptide bovine lactoferricinlactoferrampin on performance, immune function and intestinal mucosal morphology in piglets weaned at age $21 \mathrm{~d}$. Br J Nutr. 2009;101:998-1005.

52. Begum M, Hossain MM, Kim IH. Effects of fenugreek seed extract supplementation on growth performance, nutrient digestibility, diarrhoea scores, blood profiles, faecal microflora and faecal noxious gas emission in weanling piglets. J Anim Physiol Anim Nutr (Berl). 2016;100:1121-9.

53. Chen J, Kang B, Zhao Y, Yao K, Fu C. Effects of natural dietary supplementation with Macleaya cordata extract containing sanguinarine on growth performance and gut health of early-weaned piglets. J Anim Physiol Anim Nutr (Berl). 2018;102:1666-74.

54. Chen JL, Zheng P, Zhang C, Yu B, He J, Yu J, et al. Benzoic acid beneficially affects growth performance of weaned pigs which was associated with changes in gut bacterial populations, morphology indices and growth factor gene expression. J Anim Physiol Anim Nutr (Berl). 2017;101:1137-46.

55. Clarke LC, Sweeney T, Curley E, Duffy SK, Rajauria G, O'Doherty JV. The variation in chemical composition of barley feed with or without enzyme supplementation influences nutrient digestibility and subsequently affects performance in piglets. J Anim Physiol Anim Nutr (Berl). 2018;102:799-809.

56. Fang $\mathrm{CL}$, Sun $\mathrm{H}$, Wu J, Niu HH, Feng J. Effects of sodium butyrate on growth performance, haematological and immunological characteristics of weanling piglets. J Anim Physiol Anim Nutr (Berl). 2014;98:680-5.

57. Fang ZF, Peng J, Liu ZL, Liu YG. Responses of non-starch polysaccharidedegrading enzymes on digestibility and performance of growing pigs fed a diet based on corn, soya bean meal and Chinese double-low rapeseed meal. J Anim Physiol Anim Nutr (Berl). 2007;91:361-8.

58. Hosseindoust AR, Lee SH, Kim JS, Choi YH, Kwon IK, Chae BJ. Productive performance of weanling piglets was improved by administration of a mixture of bacteriophages, targeted to control Coliforms and Clostridium spp. shedding in a challenging environment. J Anim Physiol Anim Nutr (Berl). 2017;101:e98-107.

59. Kaewtapee C, Krutthai N, Poosuwan K, Poeikhampha T, Koonawootrittriron S, Bunchasak C. Effects of adding liquid DL-methionine hydroxy analogue-free acid to drinking water on growth performance and small intestinal morphology of nursery pigs. J Anim Physiol Anim Nutr (Berl). 2010;94:395-404.

60. Kluge H, Broz J, Eder K. Effect of benzoic acid on growth performance, nutrient digestibility, nitrogen balance, gastrointestinal microflora and parameters of microbial metabolism in piglets. J Anim Physiol Anim Nutr (Berl). 2006:90:316-24.

61. Lan RX, Lee $\mathrm{SI}, \mathrm{Kim} \mathbb{H}$. Effects of multistrain probiotics on growth performance, nutrient digestibility, blood profiles, faecal microbial shedding, faecal score and noxious gas emission in weaning pigs. J Anim Physiol Anim Nutr (Berl). 2016;100:1130-8.

62. Lee DN, Liu SR, Chen YT, Wang RC, Lin SY, Weng CF. Effects of diets supplemented with organic acids and nucleotides on growth, immune responses and digestive tract development in weaned pigs. J Anim Physiol Anim Nutr (Berl). 2007;91:508-18.

63. Mair C, Plitzner C, Domig KJ, Schedle K, Windisch W. Impact of inulin and a multispecies probiotic formulation on performance, microbial ecology and concomitant fermentation patterns in newly weaned piglets. J Anim Physiol Anim Nutr (Berl). 2010;94:e164-77.

64. Schone F, Vetter A, Hartung H, Bergmann H, Biertumpfel A, Richter $G$, et al. Effects of essential oils from fennel (Foeniculi aetheroleum) and caraway (Carvi aetheroleum) in pigs. J Anim Physiol Anim Nutr (Berl). 2006;90:500-10.

65. Wang DF, Zhou LL, Zhou HL, Hou GY, Zhou X, Li W. Effects of Piper sarmentosum extract on the growth performance, antioxidant capability and immune response in weaned piglets. J Anim Physiol Anim Nutr (Berl). 2017; 101:105-12.

66. Yan L, Kim IH. Effects of dietary supplementation of fermented garlic powder on growth performance, apparent total tract digestibility, blood characteristics and faecal microbial concentration in weanling pigs. J Anim Physiol Anim Nutr (Berl). 2013;97:457-64. 
67. Biagi G, Piva A, Moschini M, Vezzali E, Roth FX. Effect of gluconic acid on piglet growth performance, intestinal microflora, and intestinal wall morphology. J Anim Sci. 2006;84:370-8.

68. Biagi G, Piva A, Moschini M, Vezzali E, Roth FX. Performance, intestinal microflora, and wall morphology of weanling pigs fed sodium butyrate. J Anim Sci. 2007:85:1184-91.

69. Bosi P, Merialdi G, Scandurra S, Messori S, Bardasi L, Nisi I, et al. Feed supplemented with 3 different antibiotics improved food intake and decreased the activation of the humoral immune response in healthy weaned pigs but had differing effects on intestinal microbiota. J Anim Sci. 2011;89:4043-53.

70. Chen J, Li Y, Yu B, Chen D, Mao X, Zheng P, et al. Dietary chlorogenic acid improves growth performance of weaned pigs through maintaining antioxidant capacity and intestinal digestion and absorption function. J Anim Sci. 2018;96:1108-18.

71. Choi JY, Kim JS, Ingale SL, Kim KH, Shinde PL, Kwon IK, et al. Effect of potential multimicrobe probiotic product processed by high drying temperature and antibiotic on performance of weanling pigs. J Anim Sci. 2011:89:1795-804.

72. Davis ME, Maxwell CV, Erf GF, Brown DC, Wistuba TJ. Dietary supplementation with phosphorylated mannans improves growth response and modulates immune function of weanling pigs. J Anim Sci. 2004;82: 1882-91.

73. Di Giancamillo A, Rossi R, Pastorelli G, Deponti D, Carollo V, Casamassima D, et al. The effects of dietary verbascoside on blood and liver oxidative stress status induced by a high n-6 polyunsaturated fatty acids diet in piglets. J Anim Sci. 2015;93:2849-59.

74. Espinosa CD, Fry RS, Usry UL, Stein HH. Copper hydroxychloride improves growth performance and reduces diarrhea frequency of weanling pigs fed a corn-soybean meal diet but does not change apparent total tract digestibility of energy and acid hydrolyzed ether extract. J Anim Sci. 2017; 95:5447-54.

75. Ilsley SE, Miller HM, Kamel C. Effects of dietary quillaja saponin and curcumin on the performance and immune status of weaned piglets. J Anim Sci. 2005;83:82-8.

76. Jlali M, Briens M, Rouffineau F, Geraert PA, Mercier Y. Evaluation of the efficacy of 2-hydroxy-4-methylselenobutanoic acid on growth performance and tissue selenium retention in growing pigs. J Anim Sci. 2014;92:182-8.

77. Jo JK, Ingale SL, Kim JS, Kim YW, Kim KH, Lohakare JD, et al. Effects of exogenous enzyme supplementation to corn- and soybean meal-based or complex diets on growth performance, nutrient digestibility, and blood metabolites in growing pigs. J Anim Sci. 2012;90:3041-8.

78. Li S, Zheng J, Deng K, Chen L, Zhao XL, Jiang X, et al. Supplementation with organic acids showing different effects on growth performance, gut morphology, and microbiota of weaned pigs fed with highly or less digestible diets. J Anim Sci. 2018;96:3302-18.

79. Luo ZF, Fang XL, Shu G, Wang SB, Zhu XT, Gao P, et al. Sorbic acid improves growth performance and regulates insulin-like growth factor system gene expression in swine. J Anim Sci. 2011;89:2356-64.

80. Manzanilla EG, Nofrarias M, Anguita M, Castillo M, Perez JF, Martin-Orue SM, et al. Effects of butyrate, avilamycin, and a plant extract combination on the intestinal equilibrium of early-weaned pigs. J Anim Sci. 2006;84:2743-51.

81. Manzanilla EG, Perez JF, Martin M, Kamel C, Baucells F, Gasa J. Effect of plant extracts and formic acid on the intestinal equilibrium of early-weaned pigs. J Anim Sci. 2004;82:3210-8.

82. Marcolla CS, Holanda DM, Ferreira SV, Rocha GC, Serao NVL, Duarte MS, et al. Chromium, CLA, and ractopamine for finishing pigs. J Anim Sci. 2017; 95:4472-80.

83. Mateo RD, Spallholz JE, Elder R, Yoon I, Kim SW. Efficacy of dietary selenium sources on growth and carcass characteristics of growing-finishing pigs fed diets containing high endogenous selenium. J Anim Sci. 2007;85:1177-83.

84. Oliver WT, Wells JE. Lysozyme as an alternative to antibiotics improves growth performance and small intestinal morphology in nursery pigs. J Anim Sci. 2013;91:3129-36.

85. Oliver WT, Wells JE, Maxwell CV. Lysozyme as an alternative to antibiotics improves performance in nursery pigs during an indirect immune challenge. J Anim Sci. 2014;92:4927-34.

86. Omogbenigun FO, Nyachoti CM, Slominski BA. The effect of supplementing microbial phytase and organic acids to a corn-soybean based diet fed to early-weaned pigs. J Anim Sci. 2003;81:1806-13.
87. Omogbenigun FO, Nyachoti CM, Slominski BA. Dietary supplementation with multienzyme preparations improves nutrient utilization and growth performance in weaned pigs. J Anim Sci. 2004;82:1053-61.

88. Owusu-Asiedu A, Kiarie E, Peron A, Woyengo TA, Simmins PH, Nyachoti CM. Growth performance and nutrient digestibilities in nursery pigs receiving varying doses of xylanase and beta-glucanase blend in pelleted wheat- and barley-based diets. J Anim Sci. 2012;90(Suppl 4):92-4.

89. Shan T, Wang Y, Wang Y, Liu J, Xu Z. Effect of dietary lactoferrin on the immune functions and serum iron level of weanling piglets. J Anim Sci. 2007:85:2140-6.

90. Shen YB, Piao XS, Kim SW, Wang L, Liu P, Yoon I, et al. Effects of yeast culture supplementation on growth performance, intestinal health, and immune response of nursery pigs. J Anim Sci. 2009;87:2614-24.

91. van der Peet-Schwering CM, Jansman AJ, Smidt H, Yoon I. Effects of yeast culture on performance, gut integrity, and blood cell composition of weanling pigs. J Anim Sci. 2007;85:3099-109.

92. van Heugten E, Funderburke DW, Dorton KL. Growth performance, nutrient digestibility, and fecal microflora in weanling pigs fed live yeast. J Anim Sci. 2003;81:1004-12.

93. Walk $\mathrm{CL}$, Srinongkote $\mathrm{S}$, Wilcock P. Influence of a microbial phytase and zinc oxide on young pig growth performance and serum minerals. J Anim Sci. 2013;91:286-91.

94. Walsh MC, Sholly DM, Hinson RB, Saddoris KL, Sutton AL, Radcliffe JS, et al. Effects of water and diet acidification with and without antibiotics on weanling pig growth and microbial shedding. J Anim Sci. 2007:85:1799-808.

95. Wang Y, Shan T, Xu Z, Liu J, Feng J. Effect of lactoferrin on the growth performance, intestinal morphology, and expression of PR-39 and protegrin1 genes in weaned piglets. J Anim Sci. 2006;84:2636-41.

96. Xiao H, Tan BE, Wu MM, Yin YL, Li TJ, Yuan DX, et al. Effects of composite antimicrobial peptides in weanling piglets challenged with deoxynivalenol: II. Intestinal morphology and function. J Anim Sci. 2013;91:4750-6.

97. Xiao H, Wu MM, Tan BE, Yin YL, Li TJ, Xiao DF, et al. Effects of composite antimicrobial peptides in weanling piglets challenged with deoxynivalenol: I. Growth performance, immune function, and antioxidation capacity. J Anim Sci. 2013;91:4772-80.

98. Yang C, Zhang L, Cao G, Feng J, Yue M, Xu Y, et al. Effects of dietary supplementation with essential oils and organic acids on the growth performance, immune system, fecal volatile fatty acids, and microflora community in weaned piglets. J Anim Sci. 2019;97:133-43.

99. Yi $H$, Wang $L$, Xiong $Y$, Wen $X$, Wang $Z$, Yang $X$, et al. Effects of Lactobacillus reuteri LR1 on the growth performance, intestinal morphology, and intestinal barrier function in weaned pigs. J Anim Sci. 2018;96:2342-51.

100. Zhang GG, Yang ZB, Wang Y, Yang WR, Zhou HJ. Effects of dietary supplementation of multi-enzyme on growth performance, nutrient digestibility, small intestinal digestive enzyme activities, and large intestinal selected microbiota in weanling pigs. J Anim Sci. 2014;92:2063-9.

101. Yoon JH, Ingale SL, Kim JS, Kim KH, Lee SH, Park YK, et al. Effects of dietary supplementation of synthetic antimicrobial peptide-A3 and P5 on growth performance, apparent total tract digestibility of nutrients, fecal and intestinal microflora and intestinal morphology in weanling pigs. J Sci Food Agric. 2013;93:587-92.

102. Wu S, Zhang F, Huang Z, Liu H, Xie C, Zhang J, et al. Effects of the antimicrobial peptide cecropin $\mathrm{AD}$ on performance and intestinal health in weaned piglets challenged with Escherichia coli. Peptides. 2012;35:225-30.

103. Fabri RL, Coimbra ES, Almeida AC, Siqueira EP, Alves TM, Zani CL, et al. Essential oil of Mitracarpus frigidus as a potent source of bioactive compounds. An Acad Bras Cienc. 2012;84:1073-80.

104. Shaalan MI, El-Mahdy MM, Theiner S, El-Matbouli M, Saleh M. In vitro assessment of the antimicrobial activity of silver and zinc oxide nanoparticles against fish pathogens. Acta Vet Scand. 2017;59:49.

105. Hao X, Yang H, Wei L, Yang S, Zhu W, Ma D, et al. Amphibian cathelicidin fills the evolutionary gap of cathelicidin in vertebrate. Amino Acids. 2012;43: $677-85$.

106. Wang H, Meng XL, Xu JP, Wang J, Wang H, Ma CW. Production, purification, and characterization of the cecropin from Plutella xylostella, pxCECA1, using an intein-induced self-cleavable system in Escherichia coli. Appl Microbiol Biotechnol. 2012;94:1031-9.

107. Ghasemzadeh A, Jaafar HZ, Rahmat A, Ashkani S. Secondary metabolites constituents and antioxidant, anticancer and antibacterial activities of Etlingera elatior (Jack) R.M.Sm grown in different locations of Malaysia. BMC Complement Altern Med. 2015;15:335. 
108. Mushi NF, Mbwambo ZH, Innocent E, Tewtrakul S. Antibacterial, anti-HIV-1 protease and cytotoxic activities of aqueous ethanolic extracts from Combretum adenogonium Steud. Ex A. Rich (Combretaceae). BMC Complement Altern Med. 2012:12:163.

109. Tamamura H, Murakami T, Horiuchi S, Sugihara K, Otaka A, Takada W, et al. Synthesis of protegrin-related peptides and their antibacterial and antihuman immunodeficiency virus activity. Chem Pharm Bull (Tokyo). 1995;43: 853-8.

110. Alonso-Castro AJ, Gonzalez-Chavez MM, Zapata-Morales JR, VerdinezPortales AK, Sanchez-Recillas A, Ortiz-Andrade R, et al. Antinociceptive activity of ent-dihydrotucumanoic acid isolated from Gymnosperma glutinosum spreng less. Drug Dev Res. 2017;78:340-8.

111. Tossi A, Scocchi M, Zanetti M, Storici P, Gennaro R. PMAP-37, a novel antibacterial peptide from pig myeloid cells. CDNA cloning, chemical synthesis and activity. Eur J Biochem. 1995;228:941-6.

112. Yu H, Cai S, Gao J, Zhang S, Lu Y, Qiao X, et al. Identification and polymorphism discovery of the cathelicidins, Lf-CATHs in ranid amphibian (Limnonectes fragilis). FEBS J. 2013;280:6022-32.

113. Brahmachari G, Mandal NC, Roy R, Ghosh R, Barman S, Sarkar S, et al. A new pentacyclic triterpene with potent antibacterial activity from Limnophila indica Linn. (Druce). Fitoterapia. 2013;90:104-11.

114. Unlu M, Ergene E, Unlu GV, Zeytinoglu HS, Vural N. Composition, antimicrobial activity and in vitro cytotoxicity of essential oil from Cinnamomum zeylanicum blume (Lauraceae). Food Chem Toxicol. 2010;48: 3274-80.

115. Tayel AA, El-Tras WF, Moussa SH, El-Sabbagh SM. Surface decontamination and quality enhancement in meat steaks using plant extracts as natural biopreservatives. Foodborne Pathog Dis. 2012;9:755-61.

116. Carvalho AS, da Silva MV, Gomes FS, Paiva PM, Malafaia CB, da Silva TD, et al. Purification, characterization and antibacterial potential of a lectin isolated from Apuleia leiocarpa seeds. Int J Biol Macromol. 2015;75:402-8.

117. Boskovic M, Djordjevic J, Ivanovic J, Janjic J, Zdravkovic N, Glisic M, et al. Inhibition of salmonella by thyme essential oil and its effect on microbiological and sensory properties of minced pork meat packaged under vacuum and modified atmosphere. Int J Food Microbiol. 2017;258: 58-67.

118. Chen $\mathrm{H}$, Zhong Q. Lactobionic acid enhances the synergistic effect of nisin and thymol against Listeria monocytogenes Scott A in tryptic soy broth and milk. Int J Food Microbiol. 2017;260:36-41.

119. Chun W, Hancock RE. Action of lysozyme and nisin mixtures against lactic acid bacteria. Int J Food Microbiol. 2000;60:25-32.

120. Ma Q, Davidson PM, Zhong Q. Antimicrobial properties of lauric arginate alone or in combination with essential oils in tryptic soy broth and $2 \%$ reduced fat milk. Int J Food Microbiol. 2013;166:77-84.

121. Mathlouthi N, Bouzaienne T, Oueslati I, Recoquillay F, Hamdi M, Urdaci M, et al. Use of rosemary, oregano, and a commercial blend of essential oils in broiler chickens: in vitro antimicrobial activities and effects on growth performance. J Anim Sci. 2012;90:813-23.

122. Zanetti M, Storici P, Tossi A, Scocchi M, Gennaro R. Molecular cloning and chemical synthesis of a novel antibacterial peptide derived from pig myeloid cells. J Biol Chem. 1994;269:7855-8.

123. Ananda Baskaran S, Kazmer GW, Hinckley L, Andrew SM, Venkitanarayanan K. Antibacterial effect of plant-derived antimicrobials on major bacterial mastitis pathogens in vitro. J Dairy Sci. 2009;92:1423-9.

124. de Araujo AA, Soares LA, Ferreira MRA, Neto MAS, da Silva GR, de Araujo RF $\mathrm{Jr}$, et al. Quantification of polyphenols and evaluation of antimicrobial, analgesic and anti-inflammatory activities of aqueous and acetone-water extracts of Libidibia ferrea, Parapiptadenia rigida and Psidium guajava. J Ethnopharmacol. 2014;156:88-96.

125. Falcone PM, Mastromatteo M, Del Nobile MA, Corbo MR, Sinigaglia M. Evaluating in vitro antimicrobial activity of thymol toward hygieneindicating and pathogenic bacteria. J Food Prot. 2007;70:425-31.

126. He L, Zou L, Yang Q, Xia J, Zhou K, Zhu Y, et al. Antimicrobial activities of nisin, tea polyphenols, and chitosan and their combinations in chilled mutton. J Food Sci. 2016;81:M1466-71.

127. Rivero-Cruz I, Duarte G, Navarrete A, Bye R, Linares E, Mata R. Chemical composition and antimicrobial and spasmolytic properties of Poliomintha longiflora and Lippia graveolens essential oils. J Food Sci. 2011;76:C309-17.

128. Wei L, Yang J, He X, Mo G, Hong J, Yan X, et al. Structure and function of a potent lipopolysaccharide-binding antimicrobial and anti-inflammatory peptide. J Med Chem. 2013;56:3546-56.
129. Kelsey JA, Bayles KW, Shafii B, McGuire MA. Fatty acids and monoacylglycerols inhibit growth of Staphylococcus aureus. Lipids. 2006:41: 951-61.

130. Bukvicki D, Stojkovic D, Sokovic M, Vannini L, Montanari C, Pejin B, et al. Satureja horvatii essential oil: in vitro antimicrobial and antiradical properties and in situ control of Listeria monocytogenes in pork meat. Meat Sci. 2014;96: 1355-60.

131. Gazim ZC, Amorim AC, Hovell AM, Rezende CM, Nascimento IA, Ferreira GA, et al. Seasonal variation, chemical composition, and analgesic and antimicrobial activities of the essential oil from leaves of Tetradenia riparia (Hochst.) Codd in southern Brazil. Molecules. 2010;15:5509-24.

132. Taleb MH, Abdeltawab NF, Shamma RN, Abdelgayed SS, Mohamed SS, Farag MA, et al. Origanum vulgare L. essential oil as a potential anti-acne topical nanoemulsion-in vitro and in vivo study. Molecules. 2018;23:2164.

133. Benevides Bahiense J, Marques FM, Figueira MM, Vargas TS, Kondratyuk TP, Endringer DC, et al. Potential anti-inflammatory, antioxidant and antimicrobial activities of Sambucus australis. Pharm Biol. 2017:55:991-7.

134. Burt SA, Adolfse SJ, Ahad DS, Tersteeg-Zijderveld MH, Jongerius-Gortemaker BG, Post JA, et al. Cinnamaldehyde, carvacrol and organic acids affect gene expression of selected oxidative stress and inflammation markers in IPEC-J2 cells exposed to Salmonella typhimurium. Phytother Res. 2016:30:1988-2000.

135. Wang Q, Zhang L, Zhao J, You L, Wu H. Two goose-type lysozymes in Mytilus galloprovincialis: possible function diversification and adaptive evolution. PLoS One. 2012;7:e45148.

136. Lee JY, Boman A, Sun CX, Andersson M, Jornvall H, Mutt V, et al. Antibacterial peptides from pig intestine: isolation of a mammalian cecropin. Proc Natl Acad Sci U S A. 1989;86:9159-62.

137. Jin F, Sun $Q, X u X$, Li L, Gao G, Xu Y, et al. cDNA cloning and characterization of the antibacterial peptide cecropin 1 from the diamondback moth, Plutella xylostella L. Protein Expr Purif. 2012:85:230-8.

138. Xia L, Liu Z, Ma J, Sun S, Yang J, Zhang F. Expression, purification and characterization of cecropin antibacterial peptide from Bombyx mori in Saccharomyces cerevisiae. Protein Expr Purif. 2013;90:47-54.

139. Kim JB, Halverson T, Basir YJ, Dulka J, Knoop FC, Abel PW, et al. Purification and characterization of antimicrobial and vasorelaxant peptides from skin extracts and skin secretions of the north American pig frog Rana grylio. Regul Pept. 2000;90:53-60.

140. Liu H, Kai L, Du H, Wang X, Wang Y. LPS inhibits fatty acid absorption in enterocytes through TNF-a secreted by macrophages. Cells. 2019:8:1626.

141. Wang J, Dou X, Song J, Lyu Y, Zhu X, Xu L, et al. Antimicrobial peptides: promising alternatives in the post feeding antibiotic era. Med Res Rev. 2019; 39:831-59.

142. Hu P, Zhao F, Zhu W, Wang J. Effects of early-life lactoferrin intervention on growth performance, small intestinal function and gut microbiota in suckling piglets. Food Funct. 2019;10:5361-73.

143. Zhang H, Zhang B, Zhang X, Wang X, Wu K, Guan Q. Effects of cathelicidinderived peptide from reptiles on lipopolysaccharide-induced intestinal inflammation in weaned piglets. Vet Immunol Immunopathol. 2017:192:41-53.

144. Boskabady MH, Khatami A, Nazari A. Possible mechanism(s) for relaxant effects of Foeniculum vulgare on guinea pig tracheal chains. Pharmazie. 2004;59:561-4.

145. Srinivasan K. Black pepper and its pungent principle-piperine: a review of diverse physiological effects. Crit Rev Food Sci Nutr. 2007;47:735-48.

146. Czaplewski L, Bax R, Clokie M, Dawson M, Fairhead H, Fischetti VA, et al. Alternatives to antibiotics-a pipeline portfolio review. Lancet Infect Dis. 2016;16:239-51

\section{Ready to submit your research? Choose BMC and benefit from:}

- fast, convenient online submission

- thorough peer review by experienced researchers in your field

- rapid publication on acceptance

- support for research data, including large and complex data types

- gold Open Access which fosters wider collaboration and increased citations

- maximum visibility for your research: over $100 \mathrm{M}$ website views per year

At BMC, research is always in progress.

Learn more biomedcentral.com/submissions 